\title{
Phytochemical Analysis of Selected Medicinal Plants of India
}

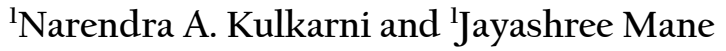 \\ Department of Botany \\ P.D.V.P. Mahavidyalaya, Tasgaon, Sangli - 416312 (MS) \\ Corresponding Author: nakul24in@yahoo.com
}

\section{$\underline{\text { Manuscript Details }}$}

Manuscript Submitted : 25/10/2018

Manuscript Revised : :25/04/2019

Manuscript Accepted : 08/05/2019

Manuscript Published : 15/05/2019

\section{$\underline{\text { Available On }}$}

https://plantaescientia.website/ojs

\section{Cite This Article As}

Kulkarni NA \& Mane Jayashree (2019). Phytochemical analysis of selected plants of India., Pla. Sci. 2019; Vol. 02 Iss. 01: 19-23.

DOI: https://doi.org/10.32439/ps.v2il.19-23

\section{Copyright}

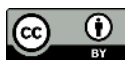

(c) The Author (s). 2019. Open Access This article is distributed under the terms of the Creative Commons Attribution 4.0 International License http://creativecommons.org/licenses/by/4.0/

\section{$\underline{\text { Indexed In }}$}

Crossref, Index Copernicus International (ICI), Directory of Research Journal Indexing (DRJI), Scientific Indexing Services (SIS),

\section{CiteFactor,}

\begin{abstract}
The present study has revealed the presence of phytochemicals considered as active medicinal chemical constituents. Important medicinal phytochemicals such as terpenoids, flavonoids, phenols, tannins, steroids, glycosides were studied in the collected samples. Plant Aegle marmelos Corr. having all these phytochemicals. Saponin was found only in two plants out of nine plants i.e. Achyranthes aspera Linn. and Semecarpus anacardium Linn. Terpenoids was found in Aegle marmelos Corr., Calotropis gigantean Linn.R.Br., Mimosa pudica Linn. Terpenoids are reported to have anti-inflammatory, anti-viral, antimalarial, inhibition of cholesterol synthesis and antibacterial. Cardiac glycosides content was found in Achyranthes aspera Linn., Aegle marmelos Corr., Mimosa pudica Linn., Tribulus terrestris Linn., Calotropis gigantea Linn.R.Br., Ricinus communis Linn.. Cardiac glycosides have been used for over two centuries as stimulant in case of cardiac failure.The flavonoids was found in Achyranthes aspera Linn., Aegle marmelos Corr., Calotropis gigantea Linn., Mimosa pudica Linn., Cissus quadrangularis Linn.Mart., Tribulus terrestris Linn. The biological functions of flavonoids apart from its antioxidant properties include protection against allergies, inflammation, free radicals, platelet aggregation, microbes, ulcers, hepotoxins, viruses and tumors.
\end{abstract}

Keywords: Medicinal plants, Phytochemicals, Secondary metabolites, Anti-inflammatory drug plants, 


\section{INTRODUCTION}

Humans have used medicinal plants since ancient time ancient records indicates the vast use of herbal medicines. In most references, it is stated that the secondary metabolites extracted from plants are subdivided into 3 major classes i.e. terpenoids, alkaloids and phenolic's. They contain numerous natural products with interesting pharmacology activities.

Plants have bioactive compounds which are used for curing of various human diseases and play on important role in healing. Phytochemicals have two categories i.e. primary and secondary constituents. Primary constituents have chlorophyll, protein, sugar and amino acid. Secondary constituents contain terpenoids and alkaloids. Medicinal plants have antifungal, antibacterial and anti-inflammation activities. The phytochemical analysis of the plants is very important commercially and has great interest in pharmaceutical companies to produce the new drugs for curing of various diseases Plant products have been part of phytomedicines since time immemorial. These can be derived from any part of the plant like bark, leaves, flowers, root, fruits, seeds etc. i.e. any part of the plant may contain active components.

The present study included plant species which were Achyranthes aspera Linn., Aegle marmelos Corr., Calotropis gigantea Linn. R. Br., Cissus quadrangularis Linn. Mart., Jatropa curcas Linn., Mimosa pudica Linn., Ricinus communis Linn., Semecarpus anacardium Linn., Tribulus terrestris Linn.

The present study has revealed the presence of phytochemicals considered as active medicinal chemical constituents. Important medicinal phytochemicals such as terpenoids, Flavonoids, phenols, tannins, steroids, glycosides were present in the sample. The result of the phytochemical analysis shows that the nine plants are rich in at least one of flavonoids, tannin, saponin, terpenoid. Plant Aegle marmelos Corr. having all these phytochemicals. Saponin was found only in two plants out of nine plants i.e. Achyranthes aspera Linn. and Semecarpus anacardium Linn. Terpenoids was found in Aegle marmelos Corr., Calotropis gigantean Linn.R.Br., Mimosa pudica Linn. Terpenoids are reported to have antiinflammatory, anti-viral, antimalarial, inhibition of cholesterol synthesis and antibacterial. Cardiac glycosides content was found in Achyranthes aspera Linn., Aegle marmelos Corr., Mimosa pudica Linn., Tribulus terrestris Linn., Calotropis gigantea Linn.R.Br., Ricinus communis Linn.. Cardiac glycosides have been used for over two centuries as stimulant in case of cardiac failure. The flavonoids was found in Achyranthes aspera Linn., Aegle marmelos Corr., Calotropis gigantea Linn., Mimosa pudica Linn., Cissus quadrangularis Linn.Mart., Tribulus terrestris Linn. The biological functions of flavonoids apart from its antioxidant properties include protection against allergies, inflammation, free radicals, platelet aggregation, microbes, ulcers, hepotoxins, viruses and tumors.

The selected medicinal plants are the source of the secondary metabolites i.e. Flavonoids, Tannins, Steroids, Terpenoids, Cardiac glycosides. Medicinal plants play a vital role in preventing various diseases. The anti-diuretic, antiinflammatory, anti-analgesic, anticancer, antiviral, antimalarial, antibacterial, anti-fungal activities of the medicinal plants are due to the presence of the above-mentioned secondary metabolites. The phytochemical analysis of the medicinal plants is also important and have commercial interest in both research institutes and pharmaceuticals companies for the manufacturing of the new drugs for treatment of various diseases identified by our study in the local available plants.

Plant products have been part of phytomedicines since time immemorial. These can be derived from any part of the plant like bark, leaves, flowers, root, fruits, seeds etc. i.e. any part of the plant may contain active components. (Thilagavathi $e t$ al, 2015. Pandey et al, 2013; Santhi et al, 2011; Mubashir \& Wajaht, 2011).

These chemicals work with nutrient and fibers to form an integrated part of defense system against various diseases and stress condition. These chemical substances are called secondary metabolites. The medicinal plants are useful for healing as well as for curing of human diseases because of presence of phytochemical constituents.

\section{MATERIAL AND METHODS}

The present study included plant species which were, Achyranthes aspera Linn., Aegle marmelos Corr., Calotropis gigantea Linn. R. Br., Cissus quadrangularis Linn. Mart., Jatropa curcas Linn., Mimosa pudica Linn., Ricinus communis Linn., Semecarpus anacardium Linn., Tribulus terrestris Linn.(Table - 2)

\section{Preparation of plant extract}

\section{Test for phenols and tannins}

Crude extract was mixed with $2 \mathrm{ml}$ of $2 \%$ solution of $\mathrm{FeCl}_{3} \mathrm{~A}$ blue-green or black coloration indicated the presence of phenols and tannins.

\section{Test for flavonoids}

a) Shinoda test: Crude extract was mixed with few fragments of magnesium ribbon and concentrated $\mathrm{HCl}$ added drop wise. Pink scarlet colour appeared after few minutes which indicated the presence of flavonoids.

b) Alkaline reagent test : Crude extract was mixed with 2 $\mathrm{ml}$ of $2 \%$ solution of $\mathrm{NaOH}$. An intense yellow colour was formed which turned colourless on addition of few drops 
of diluted acid which indicated the presence of flavonoids.

\section{Test for saponins}

Crude extract was mixed with $5 \mathrm{ml}$ of distilled water in a test tube and it was shaken vigorously. The formation of stable foam was taken as an indication for the presence of saponins.

\section{Test for glycosides}

a) Liebermann's test: Crude extract was mixed with each of $2 \mathrm{ml}$ of chloroform and $2 \mathrm{ml}$ of acetic acid. The mixture was cooled in ice. Carefully concentrated $\mathrm{H}_{2} \mathrm{SO}_{4}$ was added. A colour change from violet to blue to green indicated the presence of steroidal nucleus, i.e., glycone portion of glycoside.

b) Salkowski's test : Crude extract was mixed with $2 \mathrm{ml}$ of chloroform. Then $2 \mathrm{ml}$ of concentrated $\mathrm{H}_{2} \mathrm{SO}_{4}$ was added carefully and shaken gently. A reddish brown colour indicated the presence of steroidal ring, i.e., glycone portion of the glycoside.

c) Keller-Kilani test : Crude extract was mixed with $2 \mathrm{ml}$ of glacial acetic acid containing $1-2$ drops of $2 \%$ solution of $\mathrm{FeCl}_{3}$. The mixture was then poured into another test tube containing $2 \mathrm{ml}$ of concentrated $\mathrm{H}_{2} \mathrm{SO}_{4}$. A brown ring at the interphase indicated the presence of cardiac glycosides.

\section{Test for steroid}

Crude extract was mixed with $2 \mathrm{ml}$ of chloroform and concentrated $\mathrm{H}_{2} \mathrm{SO}_{4}$ was added sidewise. A red colour produced in the lower chloroform layer indicated the presence of steroids. Another test was performed by mixing crude extract with $2 \mathrm{ml}$ of chloroform. Then $2 \mathrm{ml}$ of each of concentrated $\mathrm{H}_{2} \mathrm{SO}_{4}$ and acetic acid were poured into the mixture. The development of a greenish coloration indicated the presence of steroids.

\section{Test for terpenoids}

Crude extract was dissolved in $2 \mathrm{ml}$ of chloroform and evaporated to dryness. To this, $2 \mathrm{ml}$ of concentrated $\mathrm{H}_{2} \mathrm{SO}_{4}$ was added and heated for about 2 minutes. A grayish colour indicated the presence of terpenoids.

\section{RESULTS AND DISCUSSION}

This study has revealed the presence of phytochemicals considered as active medicinal chemical constituents Anubha Arora, (2013). Important medicinal phytochemicals such as terpenoids, Flavonoids, phenols, tannins, steroids, glycosides were present in the sample. The result of the phytochemical analysis shows that the nine plants are rich in at least one of flavonoids, tannin, saponin, terpenoid. Plant Aegle marmelos Corr. having all these phytochemicals. (Table2).
Saponin was found only in two plants out of 9 plants i.e. Achyranthes aspera Linn. and Semecarpus anacardium Linn. Terpenoids was found in Aegle marmelos Corr, Calotropis gigantea Linn.R.Br., Mimosa pudica Linn. Terpenoids are reported to have anti-inflammatory, anti-viral, antimalarial, inhibition of cholesterol synthesis and antibacterial. Cardiac glycosides content was found in Achyranthes aspera Linn., Aegle marmelos Corr, Mimosa pudica Linn., Tribulus terrestris Linn., Calotropis gigantean Linn. R.Br., Ricinus communis Linn. Cardiac glycosides have been used for over two centuries as stimulant in case of cardiac failure.The flavonoids was found in Achyranthes aspera Linn., Aegle marmelos Corr., Calotropis gigantea Linn. R.Br., Mimosa pudica Linn., Cissus quadrangularis Linn.Mart., Tribulus terristris Linn. The biological functions of flavonoids apart from its antioxidant properties include protection against allergies, inflammation, free radicals, platelet aggregation, microbes, ulcers, hepotoxins, viruses and tumors.

\section{CONCLUSIONS}

The selected medicinal plants are the source of the secondary metabolites i.e. Flavonoids, Tannins, Steroids, Terpenoids, Cardiac glycosides. Medicinal plants play a vital role in preventing various diseases. The anti-diuretic, antiinflammatory, anti-analgesic, anticancer, antiviral, antimalarial, antibacterial, anti-fungal activities of the medicinal plants are due to the presence of the above-mentioned secondary metabolites. The phytochemical analysis of the medicinal plants are also important and have commercial interest in both research institutes and pharmaceuticals companies for the manufacturing of the new drugs for treatment of various diseases identified by our study in the local plant of Tasgaon tehsil will be helpful in the copping different diseases of this particular region.

\section{ACKNOWLEDGEMENT}

The authors acknowledge the active participation of the research students in the present piece of work. The authors acknowledge Reshma Deshmukh, Snehal Pailwan, Shraddha Chavan, Nita Shendage, Ajit Chavan and Suyog Birane.

\section{REFERENCES}

Anubha Arora, (2013). Phytochemical analysis of methanolic extracts of leaves of some medicinal plants. Biol Forum - An Int J., 5(2): 91-93.

Mubashir S and Wajaht AS, (2011). Phytochemical and Pharmacological Review Profile of Adiantum venustum. Int J Pharm Tech Res., 3: 827-830.

Pandey P, Mehta R and Upadhyay R. (2013). Physicochemical and preliminary phytochemical screening of Psoralea corylifolia. Arch Appl Sci Res., 5:261-265. 
Santhi R, Lakshmi G, Priyadharshini AM and Anandaraj, (2011). Phytochemical screening of Nerium oleander leaves and Momordica chrantia leaves. Inter Res J Pharm., 2: 131-135.

Shanmugam S, Sathish Kumar T and Panneer Selvam K, (2010). Laboratory handbook on Biochemistry.. PHI learning private limited Delhi.

Solomon CU, Arukwe UI and Onuoha Ifeanyi, (2013). Preliminary phytochemical screening of different solvent extracts of stem bark and roots of Dennetia tripetala $G$. Baker. As J Pl Sci Res., 3(3):10-13.

Thilagavathi T, Arvindganth R, Vidhya D and Dhivya R, (2015). Preliminary Phytochemical screening of different solvent mediated medicinal plant extracts evaluated. Int. Res. J. Pharm., 6(4):246 -248. https://doi.org/10.7897/2230-8407.06455

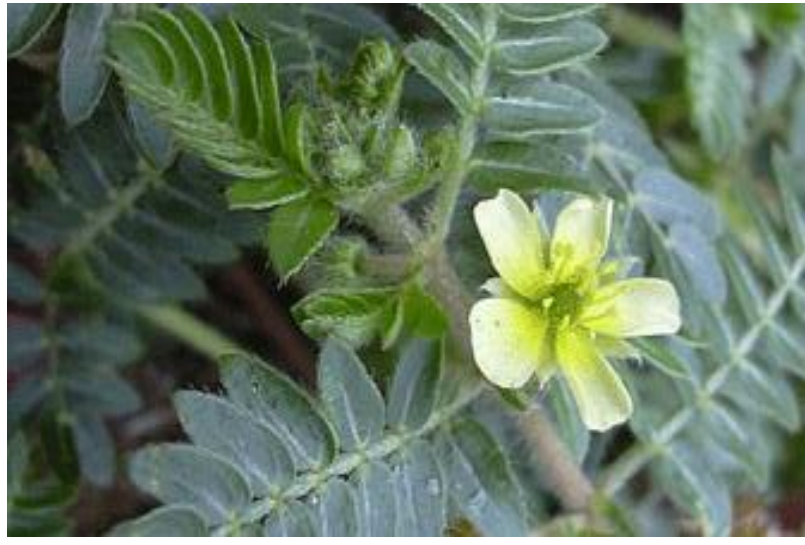

Tribulus terrestris Linn.

V. Nandagoapalan, A. Doss and C. Marimuthu, (2016). Phytochemical Analysis of Some Traditional Medicinal Plants. Bioscience Discovery, 7(1):17-20.

Table 1: List of plants used for study

\begin{tabular}{|c|c|c|c|c|}
\hline Sr.No & Botanical Name & $\begin{array}{l}\text { Vernacular } \\
\text { Name }\end{array}$ & Family & Parts used \\
\hline 1 & Achyranthes aspera Linn. & Aghada & Amaranthaceae & Roots, seed, whole plant \\
\hline 2 & Aegle marmelos Corr. & Bel & Rutaceae & Leaves, fruit, unripe fruit. \\
\hline 3 & Calotropis gigantea Linn. R. Br & Rui & Apocyanaceae & Root bark, leaves, leaf, latex, seeds. \\
\hline 4 & Cissus quadrangularis Linn. Mart & Kandvel & Vitaceae & Stem \\
\hline 5 & Jatropa curcas Linn. & Mogali Erand & Euphorbiaceae & Flowers, seed, Bark, latex \\
\hline 6 & Mimosa pudica Linn. & Lajalu & Mimosaceae & Whole plant dry root, leaves, seeds. \\
\hline 7 & Ricinus communis Linn. & Erandi & Euphorbiaceae & Seed, root, leaves \\
\hline 8 & Semecarpus anacardium Linn. & Biba & Anacardiaceae & Fruit, leaves \\
\hline 9 & Tribulus terrestris Linn. & Gokhru & Zygophyllaceae & Fruit, leaves. \\
\hline
\end{tabular}

Table 2: Qualitative Phytochemical analysis of selected medicinal plants.

\begin{tabular}{|c|c|c|c|c|c|c|c|c|c|c|}
\hline \multirow[t]{2}{*}{ Plant Name } & \multirow[t]{2}{*}{ Phenol } & \multicolumn{2}{|c|}{ Flavonoids } & \multirow[t]{2}{*}{ Saponin } & \multicolumn{3}{|c|}{ Glycoside } & \multicolumn{2}{|c|}{ Steroids } & \multirow{2}{*}{$\begin{array}{c}\text { Terpen } \\
\text { oids }\end{array}$} \\
\hline & & $\begin{array}{l}\text { Shinoda } \\
\text { Test }\end{array}$ & $\begin{array}{l}\text { Alkaline } \\
\text { reagent } \\
\text { Test }\end{array}$ & & $\begin{array}{l}\text { Lieberm } \\
\text { ann's } \\
\text { Test }\end{array}$ & $\begin{array}{l}\text { Salkows } \\
\text { ki's Test }\end{array}$ & $\begin{array}{l}\text { Keller- } \\
\text { Kilani } \\
\text { Test }\end{array}$ & Test 1 & $\begin{array}{c}\text { Test } \\
2\end{array}$ & \\
\hline Achyranthes aspera Linn. & - & - & + & + & - & + & + & + & + & - \\
\hline Aegle marmelos Corr. & + & - & + & - & + & - & + & - & + & + \\
\hline $\begin{array}{l}\text { Calotropis gigantean } \\
\text { (L) R.Br. }\end{array}$ & - & - & + & - & - & - & + & - & + & + \\
\hline $\begin{array}{l}\text { Cissus quadrangularis } \\
\text { Linn. Mart. }\end{array}$ & - & - & + & - & - & - & - & - & + & - \\
\hline Jatropa curcas Linn. & + & - & - & - & - & + & + & + & - & - \\
\hline Mimosa pudica Linn & + & - & + & - & - & + & + & + & - & + \\
\hline Ricinus communis Linn & + & - & + & - & - & - & + & - & + & - \\
\hline Semecarpus anacardium L. & + & - & - & + & - & + & - & - & - & - \\
\hline Plibutars deipestias (ISSN 2581-589X) & - & - & + & - & - & - & $\underline{h+t}$ & plant & ienti & ebsite \\
\hline
\end{tabular}




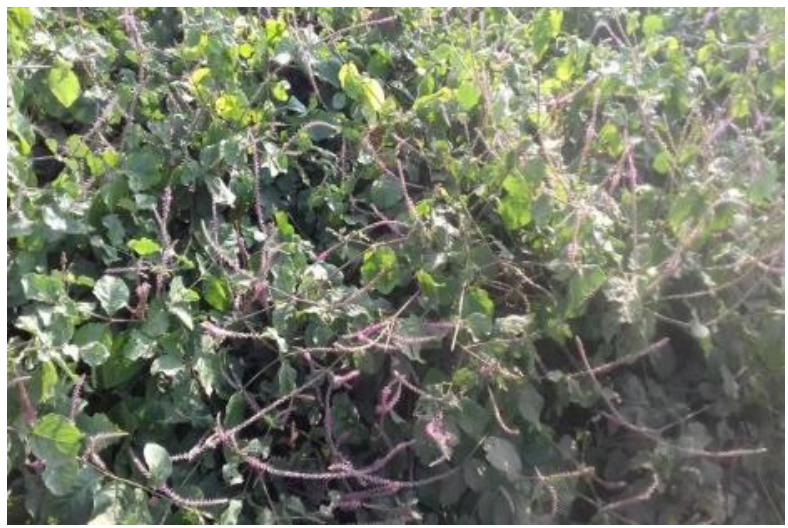

Achyranthes aspera Linn.

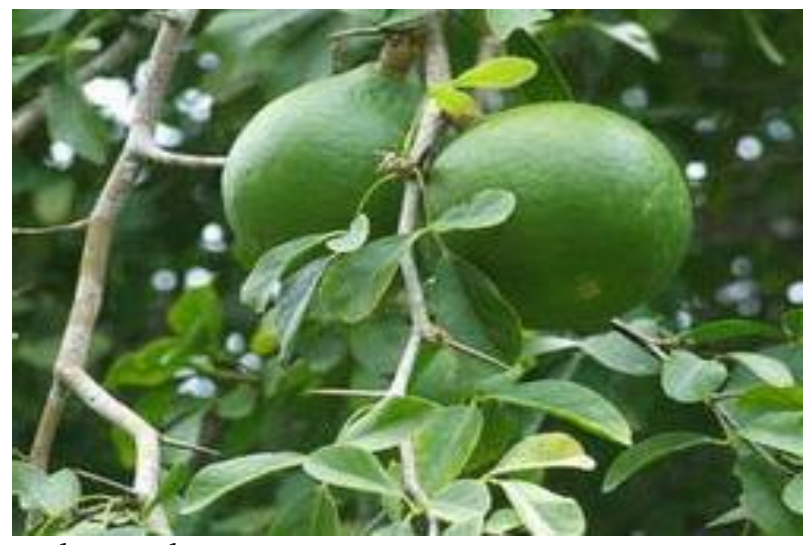

Aegle marmelos Corr.

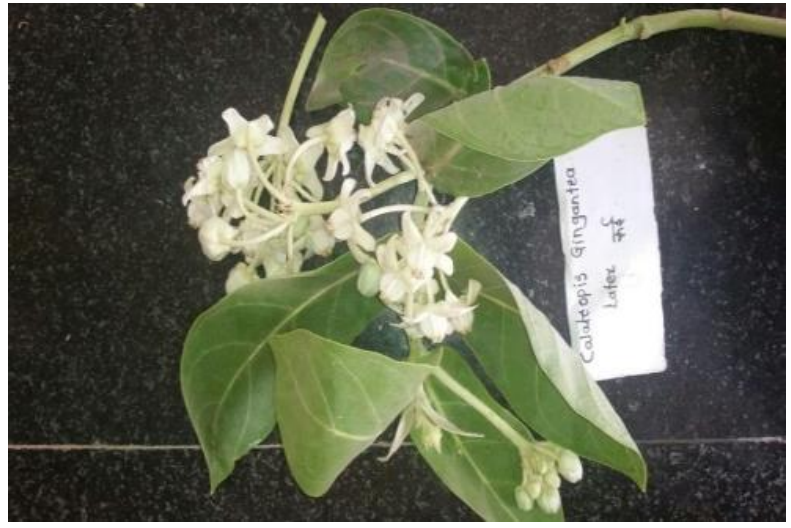

Calotropis gigantea Linn. R. Br.

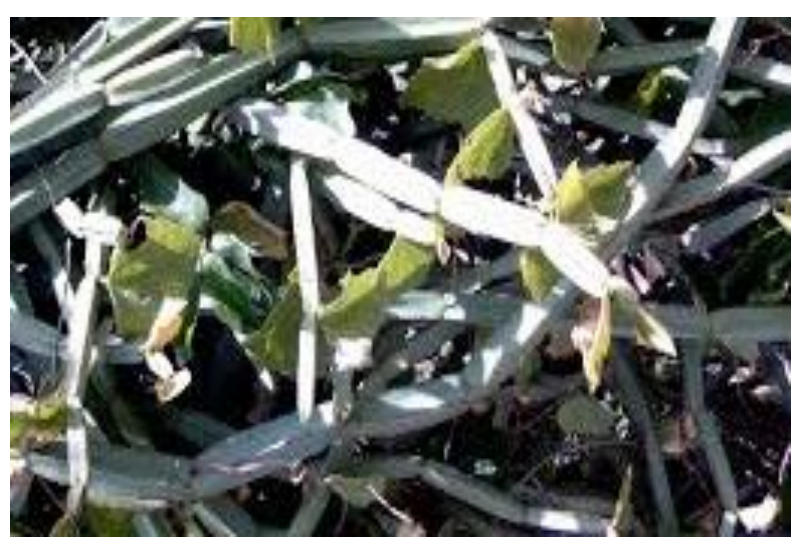

Cissus quadrangularis Linn. Mart.

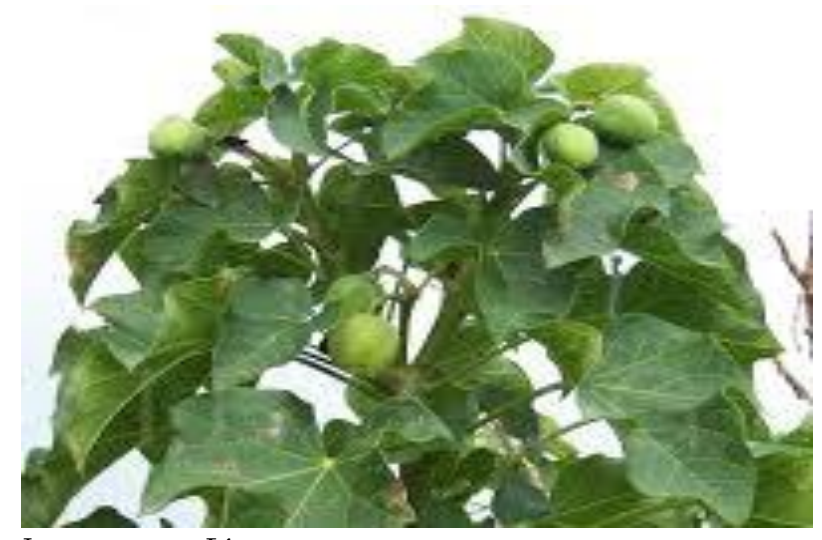

Jatropa curcas Linn.

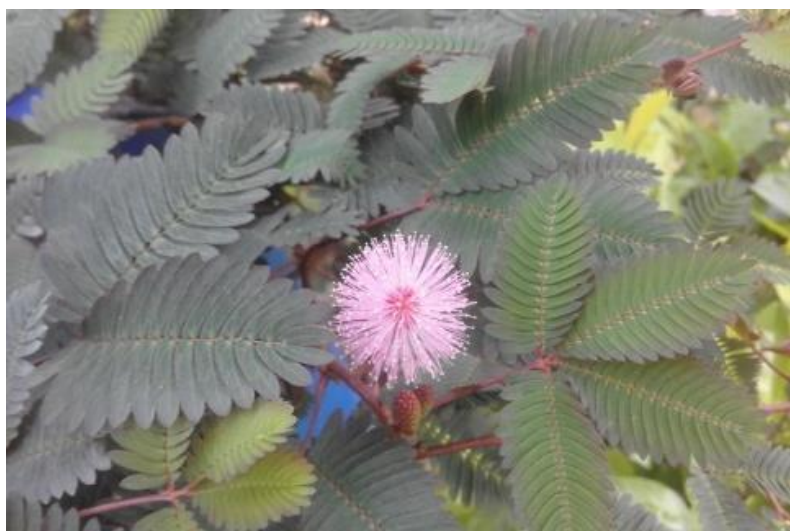

Mimosa pudica Linn.

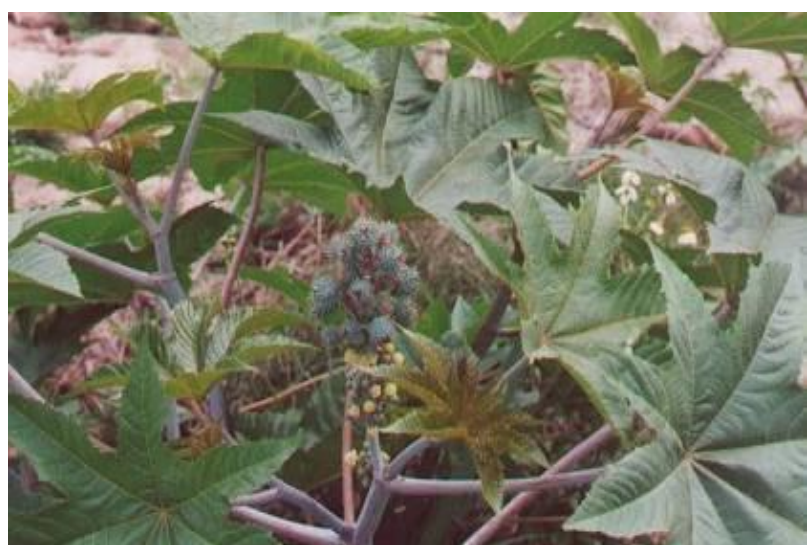

Ricinus communis Linn.

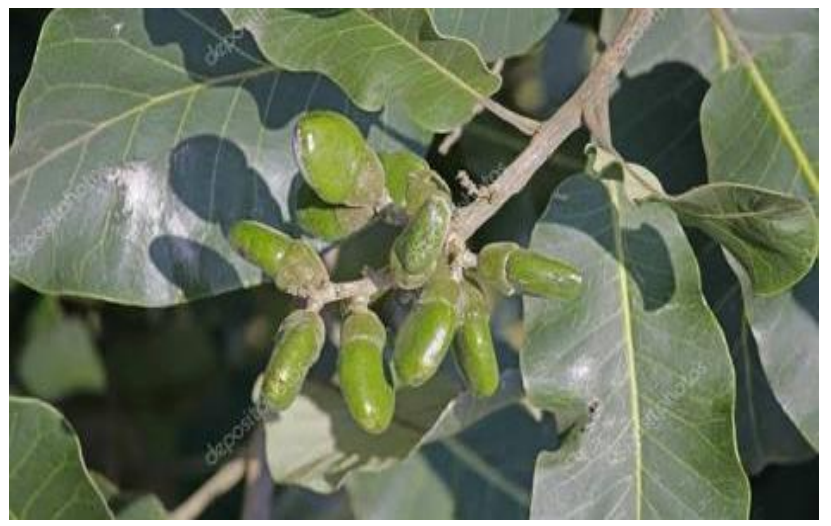

Semecarpus anacardium Linn.

○ 2019| Published by Plantae Scientia 